\title{
REVIEW
}

\section{HEALTH LITERACY OF PRIMIPARAE IN THE FIRST SIX MONTHS OF MATERNITY: REVIEW}

\author{
Ivana Olecká, Kateřina Ivanová \\ Department of Social Medicine and Public Health, Faculty of Medicine and Dentristy, Palacký University Olomouc, Czech \\ Republic
}

Received February 23, 2016; Accepted May 5, 2016. Copyright: This is an open access article distributed under the terms of the Creative Commons Attribution International License (CC BY). http://creativecommons.org/licenses/by/4.0/

\begin{abstract}
Aim: The aim of this study was to find out how the health literacy of primiparae in the first six months of motherhood is examined. The following research questions were raised: What methods are used to examine maternal health literacy? What aspects of maternal health literacy are investigated? Do the results prove any link between maternal health literacy and child health? Design: Review. Methods: The search for primary research studies was based on a combination of the following keywords: health literacy, mother, maternity, information, and knowledge in the Scopus and Web of Science databases. Exclusion criteria: not a primary study, does not concern research on primiparae of children under six months, unrelated to health literacy research or obtaining of information and acquiring of knowledge, not available in full-text, or clear research methodology description not available. The data were processed using thematic analysis based on the sorting method. Results: 31 studies were found, 17 of which were analysed. The majority of studies used quantitative methods of research with standardized tools. The key categories of health literacy related to obtaining, understanding and use of health information. No direct correlation was clearly demonstrated between level of maternal health literacy and child health. Conclusion: The trend in terms of the focus and goals of professional studies, regardless of cultural or national context, is a shift away from examining the way information is acquired to how it is understood by mothers.
\end{abstract}

Keywords: health literacy, motherhood, primiparae, symbiotic period, measuring tools for health literacy.

\section{Introduction}

According to Holčík (2011), it is not the number of medical facilities and their equipment that is essential to human health, but rather the conditions that the people live in and a healthy lifestyle. Mere detection of disease in the population, delaying of death, and improvments in the prevention of individual diseases are not enough. We need to focus more on the healthy period of life with the intention of extending it as long as possible. The basic prerequisite for lifelong health, according to the Health 21 Programme of the World Health Organization (WHO) (2002), is a healthy start in life, which includes life events such as birth, physical development, acquisition of basic social and physical values, and the strengthening of bonds with parents and close family members. The importance of a healthy start in life is underlined in descriptive research and intervention studies, indicating that the

Corresponding author: Ivana Olecká, Department of Social Medicine and Public Health, Faculty of Medicine and Dentristy, Palacký University Olomouc, Sladkovského 1200/1C, Olomouc, Czech Republic; e-mail: ivana.olecka@upol.cz foundations of health in adulthood are established in early childhood (Wilkinson, Marmot, 2005). A good start in life means that mothers support their young children, and the health consequences of early development and education last for life: "Infant experience is important for future health due to the continued malleability of biological systems" (Wilkinson, Marmot 2003).

In the first six months of a child's life, the mother is accepted as an important part of the child's own being; this is known as the symbiotic period (cf. Vágnerová, 2007). The mutual tuning of empathy and understanding between the mother and the child are characteristic of this period (Plháková, 2006). Although the bond between the mother and the child is usually established during pregnancy, the actual role of the mother as caregiver begins only after the birth. It is primarily the mother who makes healthrelated decisions on behalf of the child in this early period. The correctness of the decisions related to health is closely linked to level of health literacy (cf. Parker et al.,1995; Kickbusch, 2001; DeWalt, 2004). The baby's health is therefore closely 
connected to the health literacy of its mother in the symbiotic period.

Health literacy (HL) is understood as literacy in the area of health. It is the extent to which individuals can obtain, process and understand basic information and services necessary to make appropriate decisions about health. However, health literacy means much more: it also depends on the skills, preferences, and expectations, as well as on the provider of information and services. Health literacy is defined as the set of personal, cognitive and social skills which determine the motivation and ability of individuals to access, understand and use information to promote and maintain good health (Nutbeam, 2001).

It can be difficult to identify a person with a low level of health literacy (Kempner, 2003). To produce an effective and focused increase in health literacy, we would therefore benefit from a tool that could determine the initial level of health literacy and make clear what information should be provided to a particular mother, to what extent, and in which form.

The measurement of health literacy has already been the target of a series of standardized instruments (Olecká, Ivanová, Vencová, 2015). However, it is not entirely clear, which of these tools (if any) is best for measuring maternal health literacy in primiparae. This paper is a review of research studies ascertaining and measuring health literacy in primiparae in the first six months of motherhood.

\section{Aim}

The aim of this review was to find out how maternal health literacy in the first six months of motherhood (the symbiotic period) is examined. Three research questions were posed:

1. What methods are used to examine maternal health literacy in the first six months of motherhood?

2. What aspects of maternal health literacy are investigated?

3. Do the results prove any link between maternal health literacy and child health?

\section{Methods}

The methods of this study comply with PRISMA recommendations (check list and diagram). The search strategy for scientific papers was created according to Greenhalgh, who requires that the formulation of the problem contain answers to the following questions:

1. Who is the question about?
2. What to do with those that the question concerns? and

3. What is the desired outcome? (Greenhalgh, 2003)

\section{Eligibility criteria}

The research problem of the study focuses on primiparae in the first six months of a child's life. Primiparae of children in the symbiotic period were selected as the target group for the following main reasons:

1. It is the period in which the closest link between mother and child exists (Plháková, 2006).

2. It is the first period the primipara provides health care to her own child in practice.

3. The mother is automatically the legal guardian of the child and makes all the decisions on its behalf.

4. The degree to which the mother is able to handle her new role affects the child's health for life (Health 21, 2002).

5. The problems that the mother addresses during pregnancy (nutrition, pregnancy, childbirth...) are fundamentally different from the problems addressed in the early stages of motherhood (breastfeeding, immunization, healthy child development ...) (Ivanová, Olecká 2016).

An appropriate method for measuring and evaluating health literacy in this target group was investigated. The desired outcome was the creation of a database of knowledge for subsequent research of health literacy in this target group in the Czech Republic. Primary research studies were investigated. Three key categories were identified based on the formulated problem: investigation methods, mothers, and health literacy. After the literature review, these categories were divided into variables according to the following Scheme 1.

The category research methods was investigated from the content of professional papers in the section in which the authors describe how their research was conducted. The most frequently used methods were determined. We also investigated what methods were not represented in the context of the research cohort. The following variables were monitored in this category:

- study aim: determined from the content of professional papers in the section in which the authors describe their research aims. The objective of the research studies was determined.

- approach method: determined from the content of professional papers in the section in which the authors describe their methods, or from the abstract. Quantitative and qualitative methods were monitored individually. 
- data collection method / measurement tool: determined from the content of professional papers in the section in which the authors describe their research specifics. We investigated what research methods and techniques were used, or which specific tool was used to measure health literacy.

- analysis method: determined from the content of professional papers in the section in which the authors describe their research cohort characteristics. We investigated how the data were analysed and what kind of approach was used in their interpretation.

\section{Mothers category:}

- composition and size of the research cohort: determined from the content of professional papers in the section in which the authors describe the characteristics of the study sample. We also observed the composition of the research sample if provided by the authors. This variable examined the representativeness and the possibility of generalizing about the research studies. We identified the papers that reported on primiparae taking care of their child during its first six months. This period was not specified more precisely in any of the studies. Some studies also followed a group of multiparae; others investigated mothers of older children or pregnant women for comparison.

- Impact of maternal health literacy on the child's health: determined from the content of professional papers in the section in which the authors describe their research results. This variable answers the question "does maternal health literacy affect the child's health? ", using the variants: "yes" / "no" / "the research does not address this issue". In addition, particular monitored aspects affecting the child's health as a result of maternal health literacy were included.

Investigated aspects of health literacy:

- keywords: collected from the "keywords" section. This variable adds information about the objective and focus of the research and serves to guide the search for HL key terms.

- HL key terms: determined from the contents of specialised papers, either in the section in which the authors list the variables investigated, or derived from the context of the article. These variables extend the findings monitored by the research aim variable. This information was often stated or summarized in the conclusion of the paper, or found continuously throughout the text.

\section{Sources}

The research papers were found in the Scopus and Web of Science databases between July and August 2015.

What methods are used to examine maternal health literacy in the first six months of motherhood?

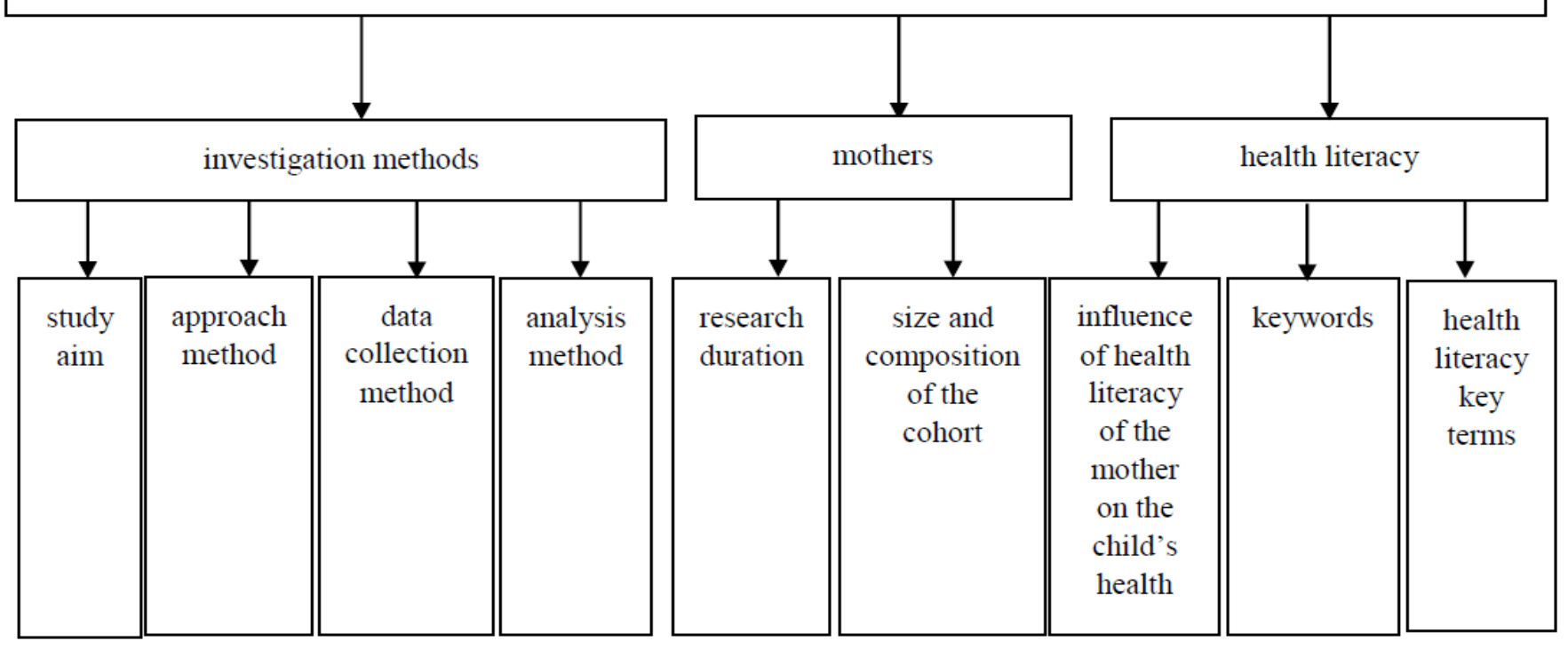

Scheme 1 Operationalization of basic categories to variables 


\section{Search}

Based on the research questions derived from the research aim (How is maternal health literacy investigated in the first six months of motherhood?), we searched for combinations of these keywords: health literacy, mother*, maternity*, information, knowledge (NB: *denotes that all forms with this root were searched). Higher limitations did not provide any results.

\section{Study selection and data analyses}

The relevance of retrieved studies was assessed in the secondary step. The assessment of the relevance of the studies was performed in two phases in accordance with Klugarová et al. (2015). In the first phase, the title and abstract were assessed with regard to the relevance of texts in terms of the research question. The following exclusion criteria were used: 1 . not a primary study; 2 . does not deal with the research of primiparae as mothers of children under six months; 3 . unrelated to health literacy research and obtaining of information and acquiring of knowledge; 4. not available in full-text; 5. no clear description of research methodology. In the second stage, we evaluated the full-text in terms of the purity of the methodology used. The papers were subsequently classified in terms of their approach to quantitative and qualitative research. They were carefully studied and the information provided was divided into variables and indicators (see Tab. 1 and Tab. 2).

After entering all the data in tables, we performed a thematic analysis using the sorting method (cf. Kane, Trochim, 2007, p. 72). Each item in the tables was recorded on an individual card, and these cards put into groups according to their meaning, after which each pile was labelled. The following rules were observed: 1 . no pile may comprise only one card; 2. no card may be in more than one pile. The sorting results were again recorded in the tables. (Scheme 2)
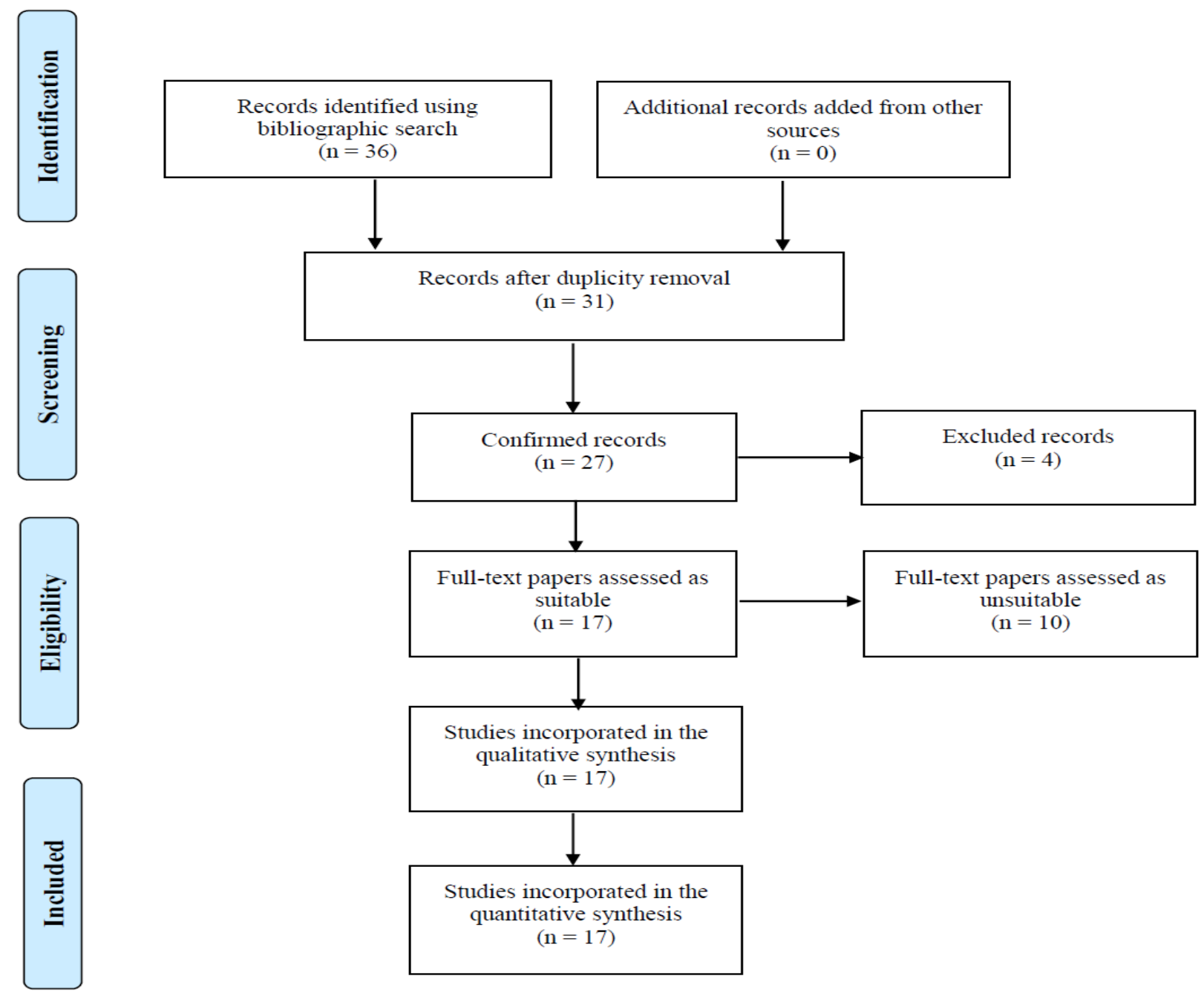

Scheme 2 Flowchart - PRISMA recommendations 


\section{Results}

The chosen search strategy returned a total of 31 studies. After implementing the exclusion criteria, 17 of these studies were analysed (see Scheme 2). The earliest article analysed was from 2001, and the most recent from 2015. The majority of the research was quantitative in nature -11 in total. Qualitative research included semi-structured interviews, indepth interviews, a combination of interviews, and focus groups as methods of data collection. The analysis made use of thematic analysis, ethnography and narrative research, using the method of understanding. In one qualitative study the method of analysis was not described at all. Quantitative studies mostly used standardized tests to measure the HL REALM, TOFHLA, WRAT-3, SASH, PHLAT, and NVS. One research study used a secondary analysis of statistical data from the census, while another used structured interviews. Custom-made questionnaires were used less frequently - and then more as a supplement to other tests. The method of data analysis in all the quantitative studies was statistical.

The cohort size in the qualitative studies was relatively high in all studies, each consisting of more than 20 participants. The largest cohort size in qualitative research was used in a study with a combination of focus groups and interviews; its cohort consisted of 112 participants. The ethnographic study, in which a total of 100 ethnically diverse families were interviewed, was also very extensive. Conversely, the cohorts in the quantitative studies were more diverse. The smallest cohort was used in a study which investigated and compared 15 primiparae and 15 multiparae. The largest cohort was used in a study based on data from a census. Only four studies strictly distinguished between primiparae and the mothers with two or more children.

The key category of health literacy analysed in the submitted studies primarily concerned the need to obtain information, the method of information acquisition - in terms of resources, the understanding of information, information retention, and the use of health information. Emphasis was placed on the way information was provided: in the native language, with respect to cultural background. The following variables were of interest: knowledge, readiness to accept the information, the correct timing of information provision, the right amount of information, and self-reliance,. in terms of information and skills acquisition. The studies also focused on the type of support provided to mothers. In addition, two studies investigated the relationship and degree of acculturation and HL. HL was measured as the length of schooling in three studies i.e., by general literacy.

Two studies showed a strong positive correlation between HL and maternal acculturation (measured on the Likert scale of the SASH test, which explores the extent of use of native languages vs. official languages).

Table 1 Overview of qualitative studies

\begin{tabular}{|c|c|c|c|c|c|c|c|}
\hline \multicolumn{2}{|c|}{ Identification of the paper (author, year) } & \multirow{2}{*}{$\begin{array}{l}\text { Renkert, } \\
2001 \\
X\end{array}$} & $\begin{array}{l}\text { Carolan, } \\
2005\end{array}$ & $\begin{array}{l}\text { Rowe, } \\
2006\end{array}$ & $\begin{array}{l}\text { Roche, } \\
2009\end{array}$ & $\begin{array}{l}\text { Arora, } \\
2012\end{array}$ & $\begin{array}{l}\text { Gazmarari, } \\
2014\end{array}$ \\
\hline study aim & information and skills & & $\mathrm{X}$ & $\mathrm{X}$ & $\mathrm{X}$ & $\mathrm{X}$ & $\mathrm{X}$ \\
\hline measurement tool & interviews & $\mathrm{X}$ & $\mathrm{X}$ & $\mathrm{X}$ & $\mathrm{X}$ & $\mathrm{X}$ & $\mathrm{X}$ \\
\hline data analysis methods & $\begin{array}{l}\text { thematic } \\
\text { narrative } \\
\text { ethnographic }\end{array}$ & & $\mathrm{X}$ & $\mathrm{X}$ & $\mathrm{X}$ & $\mathrm{X}$ & $\mathrm{X}$ \\
\hline research group & $\begin{array}{l}\text { up to } 50 \\
100-600\end{array}$ & $\mathrm{X}$ & $\mathrm{X}$ & $\mathrm{X}$ & $\mathrm{X}$ & $\mathrm{X}$ & $\mathrm{X}$ \\
\hline $\begin{array}{l}\text { influence of maternal } \\
\text { HL on the child's } \\
\text { health }\end{array}$ & not addressed & $\mathrm{X}$ & $\mathrm{X}$ & & $\mathrm{X}$ & $\mathrm{X}$ & $\mathrm{X}$ \\
\hline \multirow[t]{3}{*}{ keywords } & $\begin{array}{l}\text { health information } \\
\text { education, knowledge } \\
\text { of the mother }\end{array}$ & $\begin{array}{l}X \\
X\end{array}$ & $\mathrm{X}$ & & $\mathrm{X}$ & & $\mathrm{X}$ \\
\hline & $\begin{array}{l}\text { paediatric care, } \\
\text { information and social } \\
\text { support }\end{array}$ & $\mathrm{X}$ & & $\mathrm{X}$ & $\mathrm{X}$ & $\mathrm{X}$ & \\
\hline & HL & $\mathrm{X}$ & $\mathrm{X}$ & $\mathrm{X}$ & $\mathrm{X}$ & $\mathrm{X}$ & \\
\hline HL terms & information & $\mathrm{X}$ & $\mathrm{X}$ & $\mathrm{X}$ & $\mathrm{X}$ & $\mathrm{X}$ & $\mathrm{X}$ \\
\hline
\end{tabular}


Table 2 Overview of quantitative studies

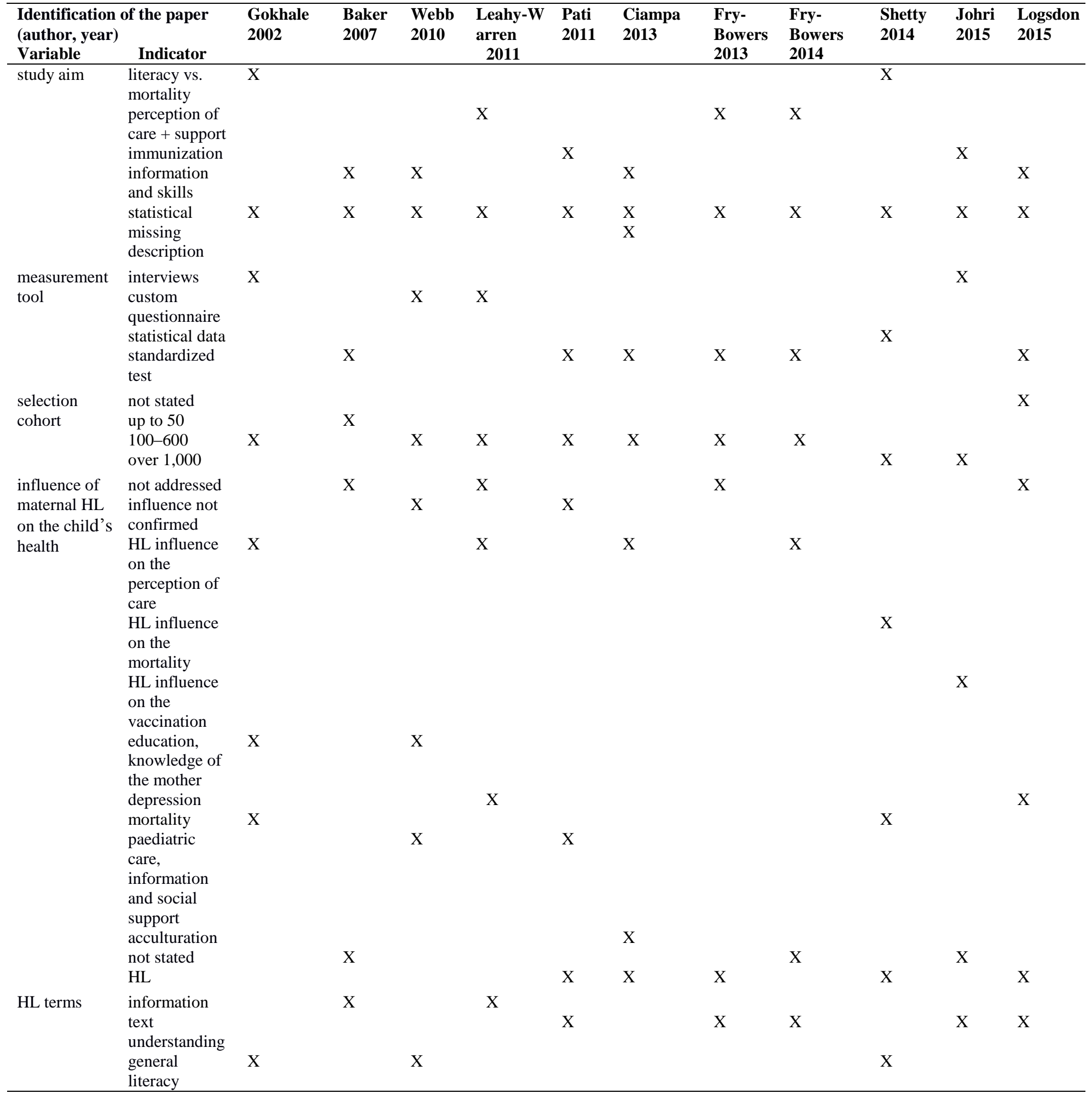

$H L-$ health literacy

The study confirmed that increasing acculturation is associated with a perception of worsening of quality of care. The study also shows a weak negative correlation between HL and reliance on professional support systems for the mothers. The study shows a positive correlation of acculturation with HL, but a weak correlation between $\mathrm{HL}$ and the skills related to child care. In total, two studies demonstrated a relationship between female literacy and infant mortality; one study showed a relationship between HL and vaccination of children. In contrast, two studies demonstrated that there was no association between $\mathrm{HL}$ and child immunization or the management of diarrhoea in children. The study reported a negative correlation between information support and postnatal depression. 


\section{Discussion}

Researchers were mostly interested in knowledge and skills acquisition in their investigations, which is the basis of the concept of health literacy in the majority of these papers. Although the analysed studies were conducted in nearly every continent (America, Europe, Australia and Asia), the topic of health literacy was approached using similar methods. In accordance with Nutbeam's definition (2011) stated in the introduction, health literacy does not consist in the mere acquisition and understanding of information. The information obtained must also be used to improve health (cf. also Holčík, 2010). As regards measuring the effects on health, the reviewed studies focused mainly on two areas: namely the impact of maternal HL on child mortality and the impact of maternal HL on immunization and vaccination of children. Effects on other areas of health were not addressed.

The analysed studies show that in addition to information acquisition, there is the issue of correct understanding of texts on health (again, in accordance with Nutbeam's definition, 2011). The studies that thematise this problem investigate in particular the health literacy of mothers whose native language differs from the official language of the country in which they live. It seems that the topical issue of minorities research is also reflected in health care (Ivanová, Špirudová, Kutnohorská, 2005). In addition to information acquisition, the thematisation of environmental influences especially social welfare, which is also perceived as a strong protective factor in the Czech context (Šolcová, Kebza, 1999) - is emerging as a specific issue in accordance with the above definition of HL .

Health literacy can be perceived as part of a coercive biomedical construct. More on the coercive biomedical construct Slepičková, Šlesingerová, Šmídová, 2012. The legitimacy of help, both social and medical, can always be viewed from two perspectives (paradigms): from the systemic perspective and from the behavioural perspective.

According to Parsons (1965), the systemic perspective presupposes a normative process control and system structure, related to a specific protective (socially or auxiliary) institute. The basis for this approach is a formal, social determination of norms for individual behaviour and, in particular, the way they are exceeded. A classic example in the case of health is the monitoring and protection of incapacitated persons (Juríčková, Ivanová, Kliment, 2011). Decisions regarding incapacitation are in the hands of doctors/psychiatrists. Exceeding the norms requires official social regulation.
In contrast, an internal view concerns the ways an individual perceives and interprets the events of everyday life. From this perspective, the only legitimate social assistance is that which is needed and demanded by the respective individual, based on their own experience (Ivanová, Juríčková, Kliment, 2010).

It follows that it is not a formally manifested social power, as it is not regulated by legal standards. Primarily, a healthy lifestyle is essential in HL. Although a healthy lifestyle is currently understood as a rational and purposeful behaviour, many authors (e.g. Illich, 1976; Foucault, 2003; Komárek, 2005; etc.) state that it is this very effort to have a healthy lifestyle that is under the influence of informal social, economic, political, cultural and, particularly, medical power. According to these authors, the evergrowing impact of medicinalization and medicalization has turned contemporary western man into an obsessive seeker of perfect health. Health is becoming a new moral value for contemporary society and is even an obligation for a civilized individual (Parusniková, 2000). By developing the cult of health, medicine based on natural sciences, with its bureaucratic organisation, is indirectly and covertly becoming a form of disciplinary power.

Stripped of the sense of "imposition", the concept of HL could be based instead on the needs of social groups and individuals. The question remains as to whether it would be useful (not only for society, but also for individuals) to totally reject the normative strengthening and maintenance of health and prevention of diseases. As demonstrated by Trpišová and Jakušová (2010), the creation and implementation of educational programs represents a significant proportion of both primary disease prevention, and health promotion.

\section{Limitation of the study}

The basic limitation of the study was the method of searching for relevant sources for analysis. Previous bibliographic searches (entering various keyword variations) on this topic found that Web of Science and Scopus provided the most varied results on health literacy of primiparae compared with other databases. The first bibliographic search showed that research and information on the topic of primiparae needs was completely missing in the Czech environment, where attention is focused primarily on two areas: information about breastfeeding and information about type of birth (vaginal x caesarean). Another group includes articles dealing with high-risk newborns. Most of these articles were not relevant to the topic of health literacy in primiparae, its measurement and 
improvement, since the condition (benefit) of the infant or toddler, rather than that of its mother, was the objective of the investigation. Bibliographic searches in EBSCO, Medline, Scopus and Web of Science databases suggest that foreign researchers are very interested in the stress experienced by mothers of preterm infants (e.g., the EBSCO database lists 1026 peer-reviewed records from 2008-2014). A large number of articles also focus on the topic of forming bonds and early interaction between mother and child. Studies on coping strategies and studies describing the experiences and expectations of mothers are closer to our topic.

Besides the limitation due to the choice of searched databases, another limitation could be seen in the restricted selection of keywords. The researchers decided to take this step based on their experience from previous bibliographic searches, in which additional keywords failed to return very relevant results for the selected topic. The search area must be interpreted broadly in this case, as further limitations to a narrower subject bring no results.

The last limitation of this study is the fact that some studies were not available in full-text, so it was not possible to include them in the analysis.

\section{Conclusion}

There is a trend in terms of the focus and goals of professional studies, regardless of cultural or national context, characterized by the shifting of attention from the examination of the means of information acquisition to the way of understanding of the mother. The concept of health literacy is defined by these concepts in the submitted studies: the need to obtain information, method of information acquisition - in terms of resources, and understanding and retention of information - and the use of health information. The trend of goals transformation is reflected in the emphasis on the content of the investigation of health literacy. While before 2011 the emphasis was laid mainly on the amount and sources of information, the present studies emphasize comprehension in particular. The information should be administered in the native language of the patient, with an emphasis on their cultural background. There is still an appeal to ensure appropriate timing of information provision and the appropriate amount of information. In some studies, HL is still measured by length of schooling.

The problem of perception of health care provision and its correlation with health literacy is starting to emerge as a new topic. Such studies are of a quantitative nature, using mostly a standardized tool.
In terms of the methods used, the studies before 2010 are predominantly quantitative. There is a tendency to identify maternal HL using existing research tools (for a review of the tools see Olecká, Ivanová, Vencová, 2015) rather than developing new ones. Along with the withdrawal of qualitative research, there is a tangible retreat from techniques designed by the researcher and the growing move towards the use of standardized quantitative tools to measure the health literacy.

A clear relationship has been proven only between health literacy of women (i.e., general literacy) and infant mortality, and between health literacy and vaccination of children. No other direct correlation between the level of maternal health literacy and child health was been clearly demonstrated. The reason is probably due to the fact that empirical evidence would be problematic from the methodological point of view in individual studies.

The presented results serve as a starting source of information for the development of primary qualitative research of HL in primiparae in the first six months of motherhood. The qualitative approach can reveal the needs of mothers and becomes an appropriate procedure for the construction of a tool that investigates $\mathrm{HL}$, freed from a purely normative framework.

\section{Ethical aspects and conflict of interest}

All the bibliographic resources used are referenced. The study is not subject to any conflict of interest. The study is based on research in the framework of the Internal Grant Agency UP number IGA_LF_2016_032 "Health literacy of mothers in the first six months of motherhood."

\section{Acknowledgments}

The authors thank prof. MUDr. Vladimir Mihál, CSc., the head of the Paediatric Department of the University Hospital in Olomouc and doc. RNDr. Peter Ondra, CSc., the head of the Department of Forensic Medicine and Medical Law, Medical Faculty of Palacky University in Olomouc for significant support in the creation of the abovementioned project.

Dedicated to the project of the Internal Grant Agency UP number IGA_LF_2016_032 "Health literacy of mothers in the first six months of motherhood."

\section{Author contributions}

Both authors participated in all stages of the elaboration of this text through interactive collaboration. 


\section{References}

Arora A, Liu MN, Chan R, Schwarz E. 'English leaflets are not meant for me': a qualitative approach to explore oral health literacy in Chinese mothers in Southwestern Sydney, Australia. Community Dentistry and Oral Epidemiology. 2012;40(6):532-541.

Baker LM, Wilson FL, Nordstrom CK, Legwand C. Mothers' knowledge and information needs relating to childhood immunizations. Issues in Comprehensive Pediatric Nursing. 2007;30(1-2):39-53.

Carolan M. Health literacy and the information needs and dilemmas of first-time mothers over 35 years. Journal of Clinical Nursing. 2007;16(6):1162-1172.

Ciampa PJ, White RO, Perrin EM, Yin HS, Sanders LM, Gayle EA, Rothman RL. The association of acculturation and health literacy, numeracy and health-related skills in Spanishspeaking caregivers of young children. Journal of Immigrant and Minority Health. 2013;15(3):492-498.

Dewalt DA, Berkman ND, Sheridan S, Lohr KN, Pignone MP. Literacy and health outcomes: a systematic review of the literature. Journal of General Internal Medicine. 2004;19(12):1228-1239.

Foucault M. Déjiny sexuality III. Péče o sebe. Praha:

Herrmann \& synové; 2003. (in Czech)

Fry-Bowers EK, Maliski S, Lewis MA, Macabasco-O'Connell A, DiMatteo R. The association of health literacy, social support, self-efficacy and interpersonal interactions with health care providers in low-income Latina mothers. Journal of Pediatric Nursing. 2014;29(4):309-320.

Fry-Bowers EK, Maliski S, Lewis MA, Macabasco-O'Connell A, Dimatteo R. Health literacy and interpersonal interactions as predictors of maternal perception of ambulatory care for low-income, Latino children. Patient Education and Counseling. 2013;91(2):213-220.

Gazmararian JA, Dalmida SG, Merino Y, Blake S, Thompson W, Gaydos L. What new mothers need to know: perspectives from women and providers in Georgia. Maternal and Child Health Journal. 2014;18(4):839-851.

Gokhale MK, Rao SS, Garole VR. Infant mortality in India: use of maternal and child health services in relation to literacy status. Journal of Health Population and Nutrition. 2002;20(2):138-147.

Greenhalkgh T. Jak pracovat s védeckou publikaci. Základy medicíny založené na di̊kazu. 1. vyd. Praha: Grada; 2003. (in Czech)

Holčík J. Systém péče o zdravi a zdravotni gramotnost: $k$ teoretickým základìm cesty ke zdraví. 1. vyd. Brno: Masarykova univerzita, MSD; 2010. (in Czech)

Holčík J. Systém péče o zdraví a zdravotní gramotnost. In: Řehulka E, editor. Výchova ke zdraví: podněty ke vzdélávacím oblastem. Škola a zdravi 21. Brno; 2011. p. 9-17. [cited 2014 Dec 18]. Available from: http://www.ped.muni.cz/z21/knihy/2011/38/texty/sbornik_ cze.pdf_(in Czech)

Illich I. Medical Nemesis. The expropriation of health. New York: Pantheon Books; 1976.

Ivanová K, Juríčková L, Kliment P. Legitimita systému opatrovnictví. In Bednárik R, Jeřábek H, Smékalová L. (eds.) Aktuálni otázky české a slovenské společnosti II. Sborník k 45. výročí založení Československé sociologické společnosti. Brno: Tribun EU, 2010; p. 265-277. (in Czech)

Ivanová K, Olecká I. Kličové kompetence matek prvorodiček v prvním pưlroce mateřství - pilotni výzkum. Nepublikované výsledky výzkumu řešeného v rámci projektu Interní grantové agentury UP číslo IGA_LF_2016_032,_Zdravotní gramotnost matek v prvním půlroce mateřstvi““. (in Czech)

Ivanová K, Špirudová L, Kutnohorská J. Multikulturní ošetrovatelstvi I. Praha: Grada Publishing, a. s.; 2005. (in Czech)

Johri M, Subramanian SV, Sylvestre MP, Dudeja S, Chandra D, Koné GK, Sharma JK, Pahwa S. Association between maternal health literacy and child vaccination in India: a cross-sectional study. Journal of Epidemiology and Community Health. 2015;69(9):849-857.

Juríčková L, Ivanová K, Kliment P. Adult guardianship system in the Czech Republic in comparison with selected European Union countries. Sociológia. 2011;43(3):266-285.

Kane M, Trochim WMK. Concept mapping for planning and evaluation. Sage; 2007.

Kempner N. Health literacy in a changing world. The

Patient's Network, IAPO. 2003;18:4-8.

Kickbusch IS. Health literacy: addressing the health and education divide. Health Promotion International. 2001;16(3):289-297.

Klugarová J, Klugar M, Marečková J, Hájek M. Methodology of systematic review development I: the effectiveness of hyperbaric oxygen therapy on mortality in adults with craniotrauma. Czech and Slovak Neurology and Neurosurgery. 2015;78/111(5):555-561.

Komárek S. Spasení těla. Moc, nemoc a psychosomatika. 1. vyd. Praha: Mladá fronta; 2005.

Leahy-Warren P, McCarthy G, Corcoran P. First-time mothers: social support, maternal parental self-efficacy and postnatal depression. Journal of Clinical Nursing. 2012;21(34):388-397.

Logsdon MC, Davis DW, Stikes R, Ratterman R, Ryan L, Myers J. Acceptability and initial efficacy of education for teen mothers. MCN The American Journal of Maternal-Child Nursing. 2015;40(3):186-192.

Marková $\mathrm{D}$, Weberová-Chvílová $\mathrm{M}$, Raušová $\mathrm{P}$ et al. Péče o předčasně narozené dítě: Kdy začíná a kdy končí? ČeskoSlovenská Pediatrie. 2014;69(1):53-62. (in Czech)

Nutbeam D. Health literacy as a public health goal: a challenge for contemporary health education and communication strategies into the 21 st century. Health Promotion International. 2000;15(3):259-267.

Olecká I, Ivanová K, Vencová B. Zdravotní gramotnost jako determinanta zdraví. Prezentace z konference MČSS. 2015. [cited 2015 May 18]. Available from: http://projekt-vavfzv.upol.cz/upload/soubory/vystupy_ka04/86_2_gramotnost_ Praha.pdf (in Czech)

Parker RM, Baker DW, Williams MV, Nurss JR. The Test of functional health literacy in adults: a new instrument for measuring patients' literacy skills. Journal of General Internal Medicine. 1995;10(10):537-541.

Parsons T. Social structure and personality. 2nd ed. New York: The Free Press; 1965.

Parusniková Z. Biomoc a kult zdraví. Sociologický časopis. 2000;36(2):131-142. (in Czech)

Pati S, Feemster KA, Mohamad Z, Fiks A, Grundmeier R, Cnaan A. Maternal health literacy and late initiation of immunizations among an inner-city birth cohort. Maternal and Child Health Journal. 2011;15(3):386-394.

Plháková A. Dějiny psychologie. Praha: Grada Publishing a.s.; 2006. (in Czech) 
Renkert S, Nutbeam D. Opportunities to improve maternal health literacy through antenatal education: an exploratory study. Health Promotion International. 2001;16(4):381-388.

Riveros JE, Martins FT. La alfabetización de la salud en el systema de saludpública en Chile. Santiago: Universidad de Chile; 2008. (in Spanish)

Roche MI, Skinner D. How parents search, interpret, and evaluate genetic information obtained from the internet. Journal of Genetic Counseling. 2009;18(2):119-129.

Rowe J, Barnes M. The role of child health nurses in enhancing mothering know-how. Collegian (Royal College of Nursing, Australia). 2006;13(4):22-26.

Shetty A, Shraddha $S$. The impact of female literacy on infant mortality rate in Indian states. Current Pediatric Research. 2014;18(1):49-56.

Slepičková L, Šlesingerová E, Šmídová I. Biomoc a reprodukční biomedicína: konceptuální inspirace pro český kontext. Sociologický časopis/Czech Sociological Review. 2012;48(1):85-106. (in Czech)
Šolcová I, Kebza V. Sociální opora jako významný protektivní faktor. Československá psychologie. 1999;43(1):19-38. (in Czech)

Trpišová M, Jakušová L. Efektivita edukácie matiek detí s pozitívnou rodinnou anamnézou. Ošetřovatelství a porodní asistence. 2010;1(2):54-56. (in Czech)

Vágnerová M. Vývojová psychologie I.: dètství a dospívání. Praha: Karolinum, 2007. (in Czech)

Webb AL, Ramakrishnan U, Stein AD, Sellen DW, Merchant M, Martorell R. Greater years of maternal schooling and higher scores on academic achievement tests are independently associated with improved management of child diarrhea by rural Guatemalan mothers. Maternal and Child Health Journal. 2010;14(5):799-806.

Wilkinson R, Marmot M. Social determinants of health: The solid facts. 2nd ed. Copenhagen: Regional Office for Europe; 2003.

Wilkinson R, Marmot M. Fakta \& souvislosti: sociálni determinanty zdravi souvislosti. Kostelec nad Černými lesy: Institut zdravotní politiky a ekonomiky; 2005. (in Czech) 